\title{
Role of Nucleolar Ribonucleic Acid in Incorporation of Ribosomal Amino-acid
}

IT is known that incorporation of amino-acids into protein by ribosomes is dependent on RNA, and thus sensitive to RNase ${ }^{1}$. It is believed that this incorporation requires a 'messenger RNA', which may have a nucleolar origin $^{2}$.

To test this hypothesis we measured the effect of nucleolar RNA, prepared according to Allfrey et al. ${ }^{3}$, on ribosomes treated with RNase (they lost 75 per cent of their RNA this way).

Table 1 gives the results of 12 experiments, which show that incorporation of either ${ }^{14} \mathrm{C}$-glycine or ${ }^{14} \mathrm{C}$-valine is enhanced by the addition of nucleolar fraction. Pretreatment of this fraction with RNase destroyed its activity.

Table 1. EFFEOT OF NUCLEOLAR RNA ON AMNO-ACID INCORPORATION

Ribosome +

nucleolar

Ribosomes + RNase treated nucleolar

fraction fraction

$$
\begin{array}{r}
\text { No } \\
1 \\
2 \\
3 \\
4 \\
5 \\
6 \\
7 \\
8 \\
9 \\
10 \\
11 \\
12
\end{array}
$$$$
\begin{array}{r}
\text { Riboso } \\
72 \\
72 \\
21 \\
158 \\
20 \\
190 \\
223 \\
480 \\
383 \\
269 \\
321 \\
280 \\
28
\end{array}
$$

Nucleolar
fraction
3
100
157
41
229
246
507
448
333
234
756

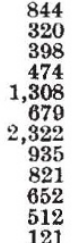

$$
121
$$

369

242

To $0.5 \mathrm{ml}$. of an incubating mixture containing $2 \mu \mathrm{mol}$. of ATP, $0.25 \mu \mathrm{mol}$. of GTP, $0.04 \mu \mathrm{mol}$. (90,000 c.p.m.) of ${ }^{14} \mathrm{C}$-glycine or ${ }^{14} \mathrm{C}$-valine (exps. 10,11 12), $10 \mu \mathrm{mol}$. of phosphoenolypyruvate, $12 \mu \mathrm{mol}$. of tris buffer $p \mathrm{H} 7.5$ and $50 \mu$ of crystalline pyruvate kinase, we added $6.5 \mathrm{mg}$ of ribosomal protein (ref. 1 ) (in $0.5 \mathrm{ml}$. of tris buffer $p \mathrm{H} 7.5,0.045 \mathrm{M}$ ), $1.5 \mathrm{mg}$ of $p \mathrm{H} 5$ enzyme (in $0.25 \mathrm{~m}$. of sucrose $0.44 \mathrm{M}$ ) and $0.4 \mathrm{mg}$ of nucleolar RNA fraction (ref. 3) (in $0.5 \mathrm{ml}$ of 0.44 sucrose). The mixture was incubated for $2 \mathrm{~h}$ at $30^{\circ} \mathrm{C}$ and the reaction stopped by adding $1 \mathrm{ml}$. of cold 10 per cent TCA. Precipitated protein for $1 \mathrm{~h}$ at room temperature in $\mathrm{N}$ sodium hydroxide.

These results agree with Sibatani, de Kloet, Allfrey and Mirsky's hypothesis ${ }^{2}$. As a matter of fact Perry ${ }^{4}$ demonstrated that some nucleolar RNA migrates to ribosomes. Recent papers ${ }^{5-7}$ have shown that synthetic polyribonucleotides can stimulate amino-acid incorporation into pre-incubated microsomes, and it is reasonable to assume that the latter are depleted of active RNA.

This work was supported by grants from the U.S. Public Health Service, Rockefeller Foundation and São Paulo State Research Foundation.

\section{Brentani \\ R. BRENTANi \\ I. RAw}

Department of Physiological Chemistry.

Faculty of Medicine,

University of São Paulo, Brazil.

${ }^{1}$ Korner, A., Biochem. J., 81, 168 (1961).

${ }^{2}$ Sibatani, A. de Kloet, S. R., Allfrey, V. G., and Mirsky, A. E., Proc. U.S. Nat. Acad. Sci., 48, 471 '(1962).

${ }^{3}$ Allfrey, V. G., and Mirsky, A. E., Proc. U.S. Nat. Acad. Sci., 43, 821 (1957).

- Perry, R., Proc. U.S. Nat. Acad. Sei., 48, 2179 (1962).

- Maxwell, E. S., Proc. U.S. Nat. Acad. Sci., 118, 1639 (1962).

- Weinstein, B., and Schechter, A. N., Proc. U.S. Nat. Acad. Sci., 48, 1686 (1962). 'Gardner, R. S., Wahba, A. J., Basilio, C., Miller, R. S., Lengyel, P., and
Speyer, J., Proc. U.S. Nat. Acad. Sci., 48, 2087 (1962).

- Sickevitz, P., J. Biol. Chem., 195, 549 (1952).

\section{Prekeratin}

Frbrous keratin is formed in the germinal or differentiating cells of keratinizing tissues and appears in the cytoplasm as birefringent fibrils. The fibrils are rich in sulphydryl groups, and electron microscopy shows that they consist of long filaments with a diameter of about $60 \AA$ (refs. 1-3). The molecular structure of prekeratin as revealed by $\mathrm{X}$-ray diffraction appears to bo similar to that of keratin ${ }^{4,5}$. Since the $\alpha$-pattern of prekeratin is readily disoriented by concentrated urea solution ${ }^{3}$, it seems that the molecular framework is primarily held together by hydrogen bonds; disulphide linkages are absent.

Only a few investigators have examined the properties of prekeratin in vitro. Rudall found that the buffered aqueous solvents commonly used for the extraction of proteins are unsatisfactory for the extraction of prekeratin. He noted, however, that copious amounts of protein can be removed from the epidermis with concentrated urea solution. In view of this, Rudall ${ }^{4}$ selected $6 \mathbf{M}$ urea solution for the extraction of prekeratin (epidermin) from the epidermis of cow's nose, and Rogers ${ }^{6}$ used $8 \mathrm{M}$ urea solu. tion for the isolation of proteins from the wool root. Analyses of the extracts thus obtained showed that they contain globular-type proteins in addition to the precursor of fibrous keratin. Complete separation of these globular proteins from prekeratin has proved very difficult ${ }^{6,7}$. The partially purified prekeratin preparations were commonly found to have a relatively low sulphur content; further. more, the bulk of the sulphur present was in the - SH form. The average molecular weight of the preparations was found to be in the range of $60,000-100,000$, thus indicating that urea splits the macromolecules of prekeratin into relatively small units. So far as the shape and molecular structure of the isolated prekeratin are concerned, it appears significant that dry films of the preparations prepared from the urea extracts were anisotropie in polarized light and showed an $\alpha$ pattern in X-ray diffraction investigations ${ }^{4,6}$.

The purpose of this communication is to report a new isolation technique by which pure prekeratin can be obtained from the epidermis of the cow's nose. This prekeratin has a high molecular weight and can be readily spun into fibres. For the isolation $0 \cdot 1 \mathrm{M}$ eitric acidsodium citrate buffer (CASC) of $p \mathrm{H} 2 \cdot 6$ and ionic strength of 0.6 was used.

After thorough washing of the cow's noses in running tap water, the epidermis is removed in sheets $0.5 \mathrm{~mm}$ thick with a keratotome (obtained from the Storz Instrument Co., St. Louis, 10, Missouri). The epidermal sheets are collected in a beaker, and, after addition of a few millilitres of CASC buffer, are cut into small pieces with scissors. The minced epidermis is afterwards suspended in CASC buffer in the ratio of $1: 5$ and homogenized in the 'VIR'TIS' apparatus for 4 min. The homogenate is then filtered through gauze and centrifuged for $10 \mathrm{~min}$ at 3,500 r.p.m. The resulting supernatant is centrifuged for $30 \mathrm{~min}$ at 20,000 r.p.m. The supernatant of this centrifugation is then diluted $1: 1$ with CA.SC buffer and the $p \mathrm{H}$ adjusted to 7 by the addition of $1 \mathrm{~N}$ sodium hydroxide drop by drop and constant stirring with a magnetic bar. The first precipitates of prekeratin appear at about $p H \quad 3 \cdot 6$. The large, sticky fibrous precipitates formed at $p H \mathbf{H}$ have a tendency to fuse and form an insoluble clot. It is advisable, therefore, to decant the supernatant fluid as soon as the precipitates settle and immodiately to add fresh CASC buffer to the precipitate. After adjustment of the $p \mathrm{H}$ to 2.6 with $0.1 \mathrm{~N}$ hydrochloric acid, the solution is stirred until all the precipitates are dissolved and the solution becomes clear. For further purification, prekeratin is serially reprecipitated at $p \mathrm{H} 6, p \mathrm{H} 5$ and finally at $p \mathrm{H} 4.5$. The precipitate thus obtained is less coherent than that previously obtained at $p H 7$ and may, therefore, be collected by brief centrifugation at 600 r.p.m. The final preparation is dialysed against CASC buffer and cleared by high-speed centrifugation for $1 \mathrm{~h}$. By this procedure approximately $\mathrm{l} g$ prekeratin may be extracted from the epidermis taken from the noses of 20 cows.

The purity of prekeratin preparations was determined by moving-boundary electrophoresis and by sedimenta. tion in the Beckman-Spinco analytical ultracentrifuge. The preparations appear monodisperse on electrophoresis in CASC buffer (Fig. 1) and form a single component on ultracentrifugation (Fig. 2). The sedimentation coefficient of prekeratin, corrected to water and extrapolated to 